\title{
RELEVANSI ANTARA PEMIDANAAN INDONESIA DAN SANKSI PIDANA ISLAM
}

\author{
Abdul Syatar \\ Mahasiswa Pasca Sarjana Program Doktor UIN Alauddin Makassar \\ Email: catajie@yahoo.co.id
}

\begin{abstract}
Positive crimes and Islamic crimes are the same in terms of determining a crime and violation. The difference lies in the aspect of punishment which is known as punishment. Although there is an element of difference between the two, it has a point of relevance of objectives between Indonesian criminal sanctions and Islamic criminal sanctions. This is especially related to the divine value between Islamic criminal sanctions and Indonesian criminal sanctions. The right of Allah swt. contained in the application of Islamic criminal sanctions is one of the teachings of Islam. However, in the application of punishment in the Indonesian legal system it still included divine elements because the source of Indonesian law, namely Pancasila and the 1945 Constitution, accommodated the divine spirit. Indonesian Criminal Law has Islamic legal values in the form of divine value, education and maintaining stability in society. Thus, the peak of relevance between Islamic criminal sanctions and Indonesian criminal sanctions together requires the issue of maintaining stability in society. It is time for Muslims to unite in terms of discussing the inclusion of Islamic criminal law sanctions into the renewal of Indonesian criminal and criminal prosecution.
\end{abstract}

\begin{abstract}
Abstrak: Pidana positif dan pidana Islam sama dalam hal menentukan sebuah kejahatan dan pelanggaran. Perbedaan terletak pada aspek pemberian hukuman yang dikenal dengan pemidanaan. Walaupun ada unsur perbedaan dari keduanya, tetapi memiliki titik relevansi tujuan antara pemidanaan Indonesia dan sanksi pidana Islam. Hal yang terkait terutama dalam nilai ilahiyah antara sanksi pidana Islam dan pemidanaan Indonesia. Hak Allah swt. yang termuat dalam keberlakuan sanksi pidana Islam merupakan salah satu ajaran Islam. Akan tetapi, dalam keberlakuan pemidanaan dalam sistem hukum Indonesia pun masih memasukkan unsur ilahiyah karena sumber hukum Indonesia yaitu Pancasila dan UUD 1945 mengakomodir spirit ketuhanan. Pemidanaan Indonesia memiliki nilai-nilai hukum Islam berupa nilai ilahiyah, pendidikan dan menjaga stabilitas dalam masyarakat.. Dengan demikian, puncak relevansi antara sanksi pidana Islam dan pemidanaan Indonesia sama-sama menghendaki persoalan menjaga stablitas dalam masyarakat. Sudah saatnya umat Islam bersatu dalam hal mewacanakan untuk memasukkan sanksi hukum pidana Islam ke dalam pembaharuan pemidanaan dan pidana Indonesia.
\end{abstract}


Kata Kunci: pidana Islam, pemidanaan, sanksi pidana Islam, hukuman dalam Islam

\section{PENDAHULUAN}

Al-Qur'an dan sunah merupakan pedoman hidup yang wajib ditaati dan dijalankan oleh umat Islam. Rasulullah saw. diutus untuk melakukan berbagai perubahan secara menyeluruh dan universal, untuk mereformasi secara total kehidupan manusia yang penuh dengan ketimpangan ketika itu. Agama yang diajarkannya membawa aspirasi dan ide tentang tauhid, akhlak mulia dan keadilan sosial sesuai dengan tingkat perkembangan pemikiran dan tahapan pertumbuhan sosial saat itu. Rasulullah saw. memberikan petunjuk-petunjuk operasional dan teladan-teladan nyata melalui sunahnya.

Beberapa kenyataan yang tidak dapat ditolak adalah bahwa syariat Islam mampu menyatukan dunia secara keseluruhan dengan wilayah yang saling berjauhan, suku bangsa yang heterogen, kondisi budaya berbeda dan persoalan temporal yang selalu berganti. ${ }^{1}$ Hukum Islam dapat memenuhi kebutuhan setiap masyarakat dan menyatukan hal-hal baru pada masa yang berbeda dan kondisi lingkungan yang beragam.

Perilaku manusia dalam hidup bermasyarakat dan bernegara seiring dengan kemajuan budaya dan iptek semakin kompleks bahkan multikompleks. Perilaku tersebut jika ditinjau dari hukum, ada perilaku yang dapat dikategorikan sesuai dengan norma dan ada perilaku yang tidak sesuai dengan norma. Perilaku yang sesuai dengan norma yang berlaku, tidak menjadi masalah. Perilaku yang tidak sesuai dengan norma biasanya dapat menimbulkan permasalahan di 
bidang hukum dan merugikan putusan pengadilan merupakan dasar masyarakat. $^{2} \quad$ Perilaku yang tidak yang penting bagi cerminan keadilan di sesuai norma itu menyebabkan Indonesia, termasuk putusan terganggunya ketertiban dan pengadilan berupa penjatuhan pidana ketentraman kehidupan manusia. dan pemidanaan.

Penyelewengan tersebut diklaim oleh Kedudukan hukum pidana masyarakat sebagai suatu pelanggaran Islam mendukung eksistensi Islam di dan kejahatan. Kejahatan dalam tengah kemajemukan masyarakat kehidupan manusia merupakan gejala dalam pergaulan dunia internasional. sosial yang selalu dihadapi oleh setiap Hukum pidana Islam mampu manusia, masyarakat, serta negara. diterapkan dalam kehidupan Kejahatan hanya dapat dicegah dan masyarakat, khususnya di negara yang dikurangi, tetapi sulit diberantas penduduknya mayoritas muslim atau secara tuntas.

Undang-undang Dasar 1945 menegaskan bahwa Negara Republik Indonesia adalah negara yang berdasar hukum. Indonesia menjunjung tinggi hak asasi manusia, menjamin segala warga negara bersamaan kedudukannya di dalam hukum dan pemerintahan serta menjunjung hukum dan pemerintahan itu dengan tidak ada kecualinya. ${ }^{3}$ Dengan demikian, sekurang-kurangnya materi hukumnya menjadi bagian dari hukum pidana nasional Indonesia.

Sebagian masyarakat Indonesia hanya mengetahui keberadaan kisas, potong tangan, dan rajam dari sudut pandang yang sempit. Masyarakat tersebut mengganggap bahwa hukuman tersebut sangat kejam. Akan tetapi, jika dipahami bahwa hukuman itu memberikan dampak positif, 
masyarakat bersyukur dengan keberadaan hukuman tersebut.

Hukum pidana di Indonesia perlu mengalami pembaharuan. Upaya pembaharuan hukum pidana (KUHP) Nasional yang saat ini dilakukan, khususnya dalam rangka menggantikan KUHP warisan zaman kolonial Belanda, memerlukan bahan kajian komparatif yang kritis. Pengamatan dari sudut pandang perbandingan hukum, sistem hukum pidana menurut KUHP yang berasal dari zaman Belanda (termasuk bagian dari hukum civil law system atau the RomanoGermanic family), yang berorientasi pada nilai-nilai individualisme/liberalisme, bukan satusatunya sistem atau konsep untuk memecahkan masalah hukum. Ada konsep atau sistem hukum lain yang sepatutnya dikaji untuk memantapkan upaya pembaharuan hukum pidana di Indonesia. Dengan demikian, sepatutnya dilakukan kajian perbandingan atau kajian alternatif. ${ }^{4}$ Salah satu kajian alternatif yang mendesak dan sesuai dengan ide pembaharuan hukum nasional dewasa ini adalah kajian terhadap yang bersumber dari nilai-nilai hukum adat dan hukum agama (Islam). Karakteristik masyarakat Indonesia bersifat monodualistik ${ }^{5}$ dan pluralistik $^{6}$. Sumber hukum nasional diharapkan berorientasi pada nilai-nilai hukum yang hidup dalam masyarakat. Dengan demikian, perlu dilakukan kajian perbandingan dari sudut hukum tradisional dan agama. Kajian komparatif tersebut menjadi kebutuhan dan keharusan.

Tujuan pemidanaan dalam Islam bukan sekadar sebagai pembalasan (retribution) semata, tetapi memiliki tujuan mulia lainnya sebagai pencegahan (deterrence) dan perbaikan (reformation), serta mengandung tujuan pendidikan (altahżib) bagi masyarakat. ${ }^{7}$ Tujuan 
122 | Jurnal Syari'ah dan Hukum Diktum, Volume 16, Nomor 1 Juli 2018 : 118 - 134

pemidanaan tersebut merupakan satu kesatuan utuh dalam penerapan hukum pidana Islam untuk mewujudkan kemaslahatan manusia. Keistimewaan hukum Islam tergambar dalam prinsip, teori, dan kaidah perundang-undangan yang terdapat pada syariat Islam yang kebenarannya universal.

Berdasarkan uraian tersebut, pokok masalah dalam tulisan ini adalah relevansi antara pemidanaan Indonesia sanksi pidana Islam.

\section{PEMBAHASAN}

\section{A. Memaknai Kata Relevansi}

Relevansi memiliki kata dasar dari relevan. Relevan memiliki arti yaitu bersangkut-paut atau berguna secara langsung. Pengertian relevansi adalah hubungan antara dua hal yang saling terikat apabila kedua hal itu dicocokkan satu sama lain lalu memiliki keterkaitan satu dengan yang lainnya.

Relevansi yang dimaksudkan dalam tulisan ini adalah hal-hal yang terkait dalam pemidanaan Indonesia dan sanksi pidana Islam dari aspek nilai bukan dari aspek bentuk sanksi itu.

\section{B. Memaknai Pemidanaan dan Sanksi Pidana Islam}

1. Pengertian Pemidanaan

Pemidanaan dapat diartikan sebagai tahap penetapan sanksi dan pemberian sanksi dalam hukum pidana. Kata pidana pada umumnya diartikan sebagai hukum, pemidanaan diartikan sebagai penghukuman.

Hulsman mengemukakan bahwa sistem pemidanaan (the sentencing system) adalah aturan perundang-undangan yang berhubungan dengan sanksi pidana. $^{8}$ Pemidanaan dapat diartikan secara luas sebagai suatu proses pemberian atau penjatuhan pidana oleh hakim mencakup pengertian:

a. Keseluruhan sistem (aturan perundang-undangan) untuk pemidanaan. 
b. Keseluruhan sistem untuk kejahatan sekaligus sebagai upaya pemberian/penjatuhan dan pelaksana pidana.

preventif terhadap terjadinya kejahatan

c. Keseluruhan sistem untuk serupa. Pemberian pidana atau fungsionalisasi/ operasioalisasi/ pemidanaan dapat terwujud apabila konkretisasi pidana. melihat beberapa tahap perencanaan sebagai berikut:

d. Keseluruhan sistem yang mengatur agar hukum pidana itu ditegakkan

a. Pemberian pidana oleh pembuat undang-undang.

atau dioperasikan secara konkret lalu seseorang dijatuhi sanksi. ${ }^{9}$

b. Pemberian pidana oleh badan yang berwenang.

Pemidanaan sebagai suatu tindakan seseorang penjahat dapat c. Pemberian pidana oleh instansi pelaksana yang berwenang. ${ }^{10}$

dibenarkan secara normal bukan karena pemidanaan itu mengandung Pengertian tersebut meliputi semua aturan-aturan perundangkonsekuensi positif bagi terpidana, undangan mengenai hukum pidana korban dan masyarakat. Pidana materil/ subtantif, hukum pidana dijatuhkan bukan karena berbuat jahat formal dan hukum pelaksanaan pidana tetapi agar pelaku kejahatan tidak lagi dapat dilihat sebagai satu kesatuan berbuat jahat dan orang lain takut melakukan kejahatan serupa.

sistem pemidanaan. Dengan perkataan lain, sistem pemidanaan terdiri dari Pemidanaan itu sama sekali subsistem hukum pidana subtantif, bukan dimaksudkan sebagai balas subsistem hukum pidana formal dan dendam melainkan sebagai upaya subsistem hukum pelaksanaan/ pembinaan bagi seorang pelaku eksekusi pidana. 
124 | Jurnal Syari'ah dan Hukum Diktum, Volume 16, Nomor 1 Juli 2018 : 118 - 134

2. Pengertian Sanksi Pidana Islam

Sanksi pidana Islam atau al'uqūbah al-syar'iyah adalah sanksi untuk memelihara dan menciptakan kemasalahatan umat karena melakukan perbuatan yang tidak sesuai dengan perintah al-Syäri ${ }^{11}$ Sanksi pidana Islam memiliki dasar, baik dari alQur'an, sunah maupun lembaga legislatif yang memunyai kewenangan menetapkan hukuman untuk kasus takzir.

Pemberian hukuman kepada orang yang melakukan kejahatan/tindak pidana itu bukan berarti pembalasan dendam, tetapi untuk kemaslahatan. Ibnu Taimiyah menjelaskan bahwa Allah swt. mensyariatkan hukuman sebagai rahmat bagi dan cerminan dari keinginan Allah swt. untuk berbuat baik (iḥsān) kepada hamba-hambaNya. Dengan demikian, pantas bagi orang yang memberikan hukuman kepada orang lain terhadap kesalahannya, melakukan iḥsān dan memberi rahmat kepadanya, seperti seorang ayah yang memberi pelajaran kepada anaknya dan seorang dokter yang mengobati pasiennya.

\section{Relasi antara Pemidanaan Indonesia dan al-'Uqübat al- Islämiyah}

Relasi yang penulis maksudkan dalam tulisan ini adalah dari segi aspek nilai, yaitu:

\section{Nilai Ilahiyah}

Nilai ilahiyah merupakan nilai tertinggi dan bersifat mutlak karena bersumber kepada Tuhan Yang Maha Esa. Nilai tersebut sebagai kendali dalam memilih kehidupan yang baik dan buruk. Dengan menyaksikan realitas, manusia dapat menyaksikan bahwa terdapat pelanggaranpelanggaran nilai-nilai ilahiyah di dunia. Misalnya, perampasan hak, kejahatan perkosaan, perampasan kebebasan, pencurian, korupsi, 
penggunaan obat terlarang, dasar UUD 1945 yang melandasi perkelahian, dan lain sebagainya. Negara Indonesia sebagai negara Perbuatan tidak etis yang berketuhanan. Sanksi pidana Islam dipertontonkan oleh sebagian memungkinkan menjadi bagian masyarakat yang merajalela di pembangunan dan pembaharuan berbagai sektor kehidupan yang hukum pidana nasional. Hak Allah swt. mengakibatkan runtuhnya martabat yang menjadi nilai ilahiyah yang sebuah bangsa dan negara.

Kondisi itu menunjukkan dimaksudkan dalam dasar Negara Republik Indonesia.

bahwa dalam pemberlakuan Secara yuridis formal, sanksi pemidanaan dalam kejahatan dan pidana Islam baru dapat berlaku bagi pelanggaran di Indonesia belum pemeluknya bila hukum itu memberikan solusi tentang nilai-nilai diundangkan oleh sebuah negara. agama yang terdapat dalam Hukum pidana Islam belum dapat pemidanaan. Masyarakat tidak diterapkan bagi masyarakat Indonesia, memiliki kesadaran terhadap perilaku khususnya yang beragama Islam. $^{12}$ kejahatan dan pelanggran yang Sanksi pidana Islam merupakan sanksi diperbuat. Untuk itu, nilai ilahiyah yang bersumber dari agama Islam, di bertujuan mengembangkan dan dalamnya terkandung dua aspek, yaitu membentuk pribadi pelaku dan aspek ilahiyah dan yuridis. Aspek masyarakat luas dengan kerangka ilahiyah dapat dilaksanakan oleh setiap normatif agama. individu karena berkaitan dengan Dasar filosofis Negara Republik pelaksanaan perintah dan larangan. Indonesia adalah Pancasila dan hukum Aspek yuridis dilaksakanan oleh 
pemerintah karena menyangkut sanksi hukum yang tidak bisa dilaksanakan oleh perorangan.

Sanksi pidana Islam, secara formal dan materil berisikan nilai, aturan dan sanksi berkaitan dengan tindak pidana hudud, kisas-diat, dan takzir. Konsep sanksi pidana Islam dapat menjadi sumber materi hukum pidana nasional selain hukum Barat dan adat.

Gagasan dasar memasukkan sanksi pidana Islam ke dalam hukum pidana nasional adalah karena alasan sebagai berikut:

a. Sistem hukum Islam tidak membedakan secara tegas antara konsep hukum perdata dan hukum pidana. Hukum nasional membedakan secara jelas dan tegas. Hal itu dapat dilihat dari konsep kisas dan diat yang memberikan kepada pihak korban hak untuk menuntut penjatuhan pemidanaan kepada pelaku.

b. Kepentingan korban dalam sistem pidana Islam diperhatikan. Ancaman yang diberikan kepada pelaku kejahatan bersifat tegas. Pemidanaan dalam hukum Indonesia tidak begitu berat.

c. Secara historis, penentuan bentuk dan berat ringannya sanksi pidana Islam dalam alQur'an dan sunah mencerminkan kebijaksanaan legislatif yang maju dan berkembang semakin memperhatikan prinsip-prinsip asasi rasa keadilan dan kemanusiaan dalam masyarakat. Pemidanaan dalam hukum nasional kurang mencerminkan kebijaksanaan karena berbeda pemahaman unsur pemaaf. ${ }^{13}$

Sistem hukum pidana merupakan bagian integral dari 
keseluruhan sistem kehidupan berbangsa secara nasional dilandasi oleh Pancasila. Pancasila merupakan nilai-nilai berkehidupan berbangsa yang dicita-citakan oleh bangsa Indonesia. Dalam konteks negara kebangsaan, berbagai sumber nilai dapat dikembangkan menjadi bahan masukan bagi penyusunan sistem hukum pidana nasional sepanjang dapat mewujudkan: ${ }^{14}$

a. Hukum pidana yang berketuhanan yang Maha Esa.

b. Hukum pidana yang berkemanusiaan yang adil dan beradab.

c. Hukum pidana yang mengandung nilai-nilai persatuan atau kepentingan bersama.

d. Hukum pidana yang dijiwai oleh nilai-nilai kerakyatan, hikmat kebijaksanaan, dan kekeluargaan

e. Hukum pidana yang berkeadilan sosial.
Pancasila sebagai sumber dari segala sumber hukum di Indonesia dan UUD 1945 sebagai konstitusi negara memberi kedudukan penting bagi agama. Kondisi tersebut memberi peluang yang besar dan signifikan untuk pengembangan hukum yang bersumber dari agama yaitu sanksi dalam pidana Islam. Pemerintah dan badan legislatif diharapkan dalam rangka pengembangan sanksi pidana Islam dalam sistem hukum pidana nasional meskipun masih terbatas.

Relevansi yang sinergi antara hukum pidana Islam dan sistem kehidupan masyarakat Indonesia dari aspek nilai ilahiyah merupakan nilai tambah bagi kontribusi hukum pidana Islam dalam rangka pembentukan RUU KUHP, baik menurut tinjauan pemidanaan modern, sosiologis, maupun yuridis dan filosofis.

Secara filosofis, tradisi fikih yang akrab di kalangan masyarakat Indonesia dapat dijadikan usaha 
pembaharuan hukum pidana nasional. Sila Ketuhanan Yang Maha Esa dalam Pancasila merupakan sila pertama yang mengayomi sila-sila lainnya memungkinkan dikembangkan hukum yang religius, seperti keberlakuan sanksi pidana Islam relevan digali dalam rangka pembentukan KUHP Nasional yang dibutuhkan oleh bangsa Indonesia.

\section{Nilai Perbaikan}

Nilai perbaikan merupakan
salah satu tujuan penjatuhan
pemidanaan kepada individu yang
melakukan kejahatan. Sanksi dapat
memperbaiki diri pelaku sebagai
individu terhadap keadaan internal
yang memengaruhi pelaku dalam
melakukan tindak pidana. Keadaan
internal yang dimaksudkan adalah
yang melekat pada diri pelaku berupa
kesadaran jiwa, akal dan
emosionalnya.

Pemidanaan yang berupa perbaikan tidak diatur dalam KUHP, tetapi secara esensi terdapat dalam
Pasal 44 ayat 2 KUHP yang memberi ketegasan untuk dilakukannya perbaikan kepada pelaku tindak pidana. Pasal tersebut menerangkan bahwa jika perbuatan itu tidak dapat dipertanggungjawabkan kepada pelakunya karena pertumbuhan jiwanya cacat atau terganggu karena penyakit, hakim dapat memerintahkan supaya orang itu dimasukkan ke rumah sakit jiwa.

\section{Perkembangan RUU KUHP} sebagai bentuk pembaharuan hukum pidana memunyai tujuan untuk memperbaiki pelaku sebagai suatu konsekuensi dari perkembangan teori pemidanaan dewasa ini. RUU KUHP mengatur pemidanaan yang bertujuan memperbaiki pelaku.

Nilai-nilai perbaikan dalam sanksi pidana Islam tidak diatur secara implisit dalam al-Qur'an. Akan tetapi, secara eksplisit nilai perbaikan dapat dimaknai dalam QS al-Mā'idah/5: 39: 


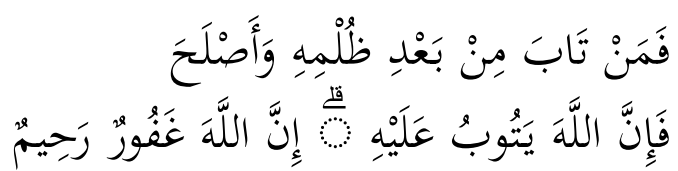

Terjemahnya:

Maka barang siapa bertobat (di antara pencuri-pencuri itu) sesudah melakukan kejahatan itu dan memperbaiki diri, maka sesungguhnya Allah menerima tobatnya. Sesungguhnya Allah Maha Pengampun lagi Maha Penyayang. ${ }^{15}$

Ayat tersebut menggambarkan bahwa adanya ampunan Allah swt. kepada para pencuri dengan cara bertobat. Akan tetapi, kadar tobat tersebut terukur dengan fakta bahwa pelaku tindak pidana mengalami perbaikan. Makna tersebut dapat diinterpretasikan sebagai suatu syarat kepada seluruh stakeholder untuk melakukan suatu upaya demi memperbaiki pelaku tindak pidana. Perbaikan yang dimaksudkan tidak menghapuskan sanksi pidananya.

Sanksi pidana Islam berfungsi sebagai zawājir (pencegah) dan jawābir (penebus). Keberadaan sanksi sebagai zawājir karena mampu mencegah manusia dari perbuatan dosa dan tindak pelanggaran. Keberadaan sanksi sebagai jawābir karena dapat menebus sanksi akhirat. Sanksi akhirat bagi seorang muslim berkurang atau gugur oleh sanksi yang dijatuhkan oleh negara di dunia. ${ }^{16}$ Penjatuhan sanksi diyakini dapat menggugurkan atau mengurangi siksaan di akhirat. Pemberian sanksi bertujuan untuk memperbaiki pelaku tindak pidana sebagai wujud konkrit dari suatu pertobatan.

Salah satu tujuan dari penjatuhan pemidanaan adalah mendidik pelaku kejahatan agar menjadi orang baik dan menyadari kesalahannya. Perhatian syariat Islam terhadap pelaku dengan penjatuhan sanksi diharapkan timbul dalam diri pelaku bentuk kesadaran bahwa pelaku menjauhi kejahatan bukan karena takut dengan sanksi, melainkan karena kesadaran diri dan kebenciannya 
terhadap jarimah serta dengan harapan mendapat rida dari Allah swt. Kesadaran tersebut merupakan alat yang ampuh untuk memberantas kejahatan.

Hakikat dari tujuan pemidanaan adalah memperbaiki pelaku dan melindugi masyarakat dalam perkembangan hukum pidana. Tujuan tersebut bukan satu-satunya tujuan pemidanaan, tetapi tujuan tersebut tepat untuk dapat mendidik individu dan masyarakat.

\section{Menjaga Stabilitas dalam Masyarakat}

Perlindungan masyarakat merupakan salah satu ide dasar dari penjatuhan pemidanaan untuk memberi rasa aman, nyaman, tentram dan tertib dengan mengupayakan seminimal mungkin mengurangi atau mencegah terjadinya tindak pidana maupun perbaikan akibat dari terjadinya tindak pidana dalam artian mengembalikan keseimbangan atau stabilitas masyarakat yang bergeser dari keadaan semula.

Pemidanaan yang termuat dalam KUHP menggambarkan sebagai salah satu upaya untuk memberikan perlindungan kepada masyarakat. Segala bentuk sanksi merupakan perlindungan karena pelaku kriminal dihukum, bertobat dan memperbaiki diri serta tidak mengkhawatirkan untuk melakukan perbuatan kriminal dalam masyarakat.

Ketentuan yang dirumuskan dalam pemidanaan untuk memberikan perlindungan maksimal kepada masyarakat. Misalnya, dengan adanya perbuatan kriminal terjadi ketidakseimbangan dalam pergaulan sosial antara manusia dengan penciptanya, manusia dengan sesamanya, maupun manusia dengan alam. Ketidakseimbangan tersebut membutuhkan suatu ketentuan sanksi 
untuk mengembalikan keseimbangan yang dimaksudkan.

Ketidakseimbangan yang terjadi dalam kehidupan masyarakat bukan saja menimbulkan kebencian kepada diri pelaku, tetapi meresahkan masyarakat jika terjadi tindak pidana yang lain. Pelaku tindak pidana yang membunuh, mencuri, memerkosa, melakukan hubungan seks di luar pernikahan yang sah, dan lain sebagainya dapat mengguncang stabilitas dalam kehidupan masyarakat.

Sanksi pidana Islam bertujuan untuk membentuk masyarakat yang baik diliputi oleh rasa saling menghormati dan mencintai antar sesama manusia dengan mengetahui batas-batas hak dan kewajibannya. Pada hakikatnya, suatu kejahatan merupakan perbuatan yang tidak disenangi dan menginjak-injak keadilan serta membangkitkan kemarahan masyarakat terhadap pelaku, lalu menimbulkan rasa iba dan kasih sayang terhadap korbannya. ${ }^{17}$

Syariat Islam hadir untuk memperbaiki akhlak atau moral umat manusia, baik itu moral terhadap Tuhan, moral terhadap sesamanya, maupun moral terhadapa alam dan makhluk lain di muka bumi. Sisi moral dalam syariat Islam merupakan sisi yang positif, bahkan tujuan hukumhukumnya dan target ajaran-ajarannya berkisar pada penyempurnaan dan pelurusan jiwa serta mengarahkan manusia ke tujuan-tujuan kebaikan dan kemaslahatan. $^{18}$ Tujuan pengutusan Rasulullah saw. demi menjaga kestabilan di muka bumi ini. Hal itu termuat dalam QS al-Anbiyā'/21: 107:

$$
\text { وَمَا أَرْسَلْنَاكَ إِلَّا زَهْمَة لِلْعَالَمِينَ }
$$

Terjemahnya:

Dan tidaklah Kami mengutus kamu (Muhammad) melainkan untuk (menjadi) rahmat bagi semesta alam. ${ }^{19}$

Ciri terpenting dari rahmat 
Allah swt. yang berpengaruh dalam diri manusia adalah akhlak yang terpuji, perilaku yang baik, hidup yang mapan, dan terjalinnya hubungan yang harmonis dengan sesama manusia.

Ketidakseimbangan yang diakibatkan oleh kejahatan dikembalikan pada kondisi semula. Keberadaan sanksi untuk memulihkan hubungan antar sesama manusia dengan pencipta, manusia dengan manusia yang lain, dan manusia dengan alam sekitarnya. Dengan keberadaan sanksi pidana Islam mampu menjaga stabilitas dalam masyarakat. Dapat dikatakan dengan bahasa ḥifz nizām al-jamā‘ah (menjaga stabilitas masyarakat) merupakan sesuatu yang sifatnya darurat dalam hirarki tertinggi maqāsid al-syarī'ah.

\section{PENUTUP}

Relevansi sanksi pidana Islam tidak sepenuhnya relevan dengan sistem pemidanaan dalam hukum
Indonesia. Hal yang terkait terutama dalam nilai ilahiyah antara sanksi pidana Islam dan pemidanaan Indonesia. Hak Allah swt. yang termuat dalam keberlakuan sanksi pidana Islam merupakan salah satu ajaran Islam. Akan tetapi, dalam keberlakuan pemidanaan dalam sistem hukum Indonesia pun masih memasukkan unsur ilahiyah karena sumber hukum Indonesia yaitu Pancasila dan UUD 1945 mengakomodir spirit ketuhanan. Pemidanaan Indonesia memiliki nilainilai hukum Islam berupa nilai ilahiyah, pendidikan dan menjaga stabilitas dalam masyarakat.. Dengan demikian, puncak relevansi antara sanksi pidana Islam dan pemidanaan Indonesia sama-sama menghendaki persoalan menjaga stablitas dalam masyarakat.

Sudah saatnya umat Islam bersatu dalam hal mewacanakan untuk memasukkan sanksi hukum pidana Islam ke dalam pembaharuan pemidanaan dan pidana Indonesia. Ego sentris yang dikedepankan dari 
golongan-golongan yang memiliki

kapasitas duduk bermusyawarah

membela umat Islam melalui

pemberlakuan hukumnya. Bagi umat

Islam yang memiliki wilayah itu agar

memberikan penjelasan tentang

keunggulan hukum pidana Islam

bahwa hukum pidana Islam lebih

efektif diberlakukan. antara satu dan lainnya.

${ }^{6}$ Pluralistik adalah sifat atau kualitas yang menggambarkan keanekaragaman dan suatu pengakuan bahwa alam semesta tercipta dalam keanekaragaman. Contoh, bangsa Indonesia mengakui bahwa Negara Indonesia bersifat pluralistik, beraneka ragam ditinjau dari suku-bangsa, adat budaya, bahasa, agama, dan lainnya. Hal ini merupakan suatu kenyataan dan keniscayaan dalam kehidupan bangsa Indonesia. Keanekaragaman tersebut harus didudukkan secara proporsional dalam kehidupan berbangsa dan bernegara yang bernilai sebagai aset negara, bukan sebagai faktor penghalang kemajuan. Pluralitas merupakan sunnatullah.

${ }^{7}$ Satria Efendi M. Zein, Prinsip-Prinsip Dasar Hukum Jinayat dan Permasalahan Penerapannya Masa Kini, Mimbar Hukum, no. 20 tahun VI (Jakarta: al-Hikmah, 1995 M.), h. 32.

${ }^{1}$ Yūsuf al-Qaraḍ̄wīi, 'Awāmil al-Sa'ah wa al-Murūnah fí al-Syarī'ah al-Islāmiyyah, terj. Agil Husain al-Munawwar, Keluasan dan Keluwesan Hukum Islam (Cet. I; Semarang: Toha Putra, 1993), h. 1.

${ }^{2}$ Bambang Waluyo, Pidana dan Pemidanaan (Cet. III; Jakarta: Sinar Grafika, 2008), h. 1.

${ }^{3}$ Bambang Waluyo, Pidana dan Pemidanaan, h. 33.

${ }^{4}$ Barda Nawawi Arief, Kapita Selekta Hukum Pidana (Cet. III; Bandung: Citra Aditya Bakti, 2013), h.35-36.

${ }^{5}$ Monodualistik adalah manusia diciptakan sebagai makhluk individu yang mempunyai hak yang hakiki dan sebagai makhluk sosial yang berinteraksi dalam masyarakat. Maksud manusia sebagai makhluk individu yaitu manusia mempunyai jati diri sendiri. Setiap manusia mempunyai suatu perbedaan yang membedakan antara satu dan lainnya, lalu menjadikan manusia tidak ada yang sama. Manusia sebagai makhluk sosial yaitu manusia yang tidak dapat hidup sendiri di dunia ini. Manusia saling membutuhkan
${ }^{8}$ L.C.H. Hulsman, The Dutch Criminal Justice System from A Comparative Legal Perspektive dalam D.C Fokkema, Introduction to Dutch Law for Foreign Lawyers (Netherlands: Kluwer Deventer, 1978), h. 320.

${ }^{9}$ Barda Nawawi Arief, Kapita Selekta Hukum Pidana (Cet. III; Bandung: PT Citra Adiya Bakti, 2013), h. 107-108.

${ }^{10}$ Amir Ilyas, Asas-asas Hukum Pidana: Memahami Tindak Pidana dan Pertanggungjawaban Pidana Sebagai Syarat Pemidanaan (Cet. I; Yogyakarta: Mahakarya Rangkang Offset, 2012), h. 95-96.

${ }^{11}$ ،Abd al-Qādir 'Audah, al-Tasyrī' alJinā'̄ al-Islāmīi; Muqāranan bi al-Qānūn alWad $^{\top} i$, Jil. I, h. 456.

${ }^{12}$ Zainuddin Ali, Hukum Islam (Jakarta: Sinar Grafika, 2006), h. 82.

${ }^{13}$ Abdul Halim Barakatullah dkk, Hukum Islam Menjawab Tantangan Zaman Yang Terus Berkembang (Yogyakarta: Pustaka Pelajar, 2006), h. 270-271.

${ }^{14}$ Muhammad Amin Suma dkk, 
Pidana Islam di Indonesia (Jakarta: Pustaka Firdaus, 2001), h.27.

${ }^{15}$ Kementerian Agama RI, Al-Qur'an dan Terjemahnya (Bandung: J-ART, 2004), h. 115.

${ }^{16}$ M. Arifin Hamid, Hukum Islam Perspektif Keindonesiaan; Sebuah Pengantar Dalam Memahami Realitasnya di Indonesia (Makassar: Umitoha Ukhuwah Grafika, 2011)), h. 241.

${ }^{17}$ Ahmad Wardi Muslich, Pengantar dan Asas Hukum Pidana Islam (Jakarta: Sinar Grafika ,2006), h. 147.

${ }^{18}$ Abdul Karim al-Khatib, Filsafat Islam; Islam Menjawab Tuduhan Penilaian Terhadap Islam (Solo: Tiga Serangkai, t.th), h. 189.

${ }^{19}$ Kementerian Agama RI, Al-Qur'an dan Terjemahnya, h. 332.

\section{DAFTAR PUSTAKA}

Ali, Zainuddin. Hukum Islam. Jakarta: Sinar Grafika, 2006.

Al-Khatib, Abdul Karim. Filsafat Islam; Islam Menjawab Tuduhan Penilaian Terhadap Islam. Solo: Tiga Serangkai.

Arief, Barda Nawawi. Kapita Selekta Hukum Pidana. Cet. III; Bandung: Citra Aditya Bakti, 2013.

'Audah, 'Abd al-Qādir. al-Tasyrī' alJinā'i al-Islāmī; Muqāranan bi alQānūn al-Waḍ'i. Kairo: Maktabah al-Taufiqiyah, 2013.

Barakatullah. Abdul Halim dkk, Hukum Islam Menjawab Tantangan Zaman Yang Terus Berkembang. Yogyakarta: Pustaka Pelajar, 2006.

Hamid, M. Arifin. Hukum Islam

Perspektif Keindonesiaan;
Sebuah Pengantar Dalam
Memahami Realitasnya di
Indonesia. Makassar: Umitoha
Ukhuwah Grafika, 2011.

Ilyas, Amir. Asas-asas Hukum Pidana: Memahami Tindak Pidana dan Pertanggungjawaban Pidana Sebagai Syarat Pemidanaan. Cet. I; Yogyakarta: Mahakarya Rangkang Offset, 2012.

Kementerian Agama RI, Al-Qur'an dan Terjemahnya. Bandung: JART, 2004.

Muslich, Ahmad Wardi. Pengantar dan Asas Hukum Pidana Islam. Jakarta: Sinar Grafika, 2006.

al-Qaraḍ̄wīi, Yūsuf. 'Awāmil al-Sa'ah wa al-Murūnah fĩ al-Syarī'ah alIslämiyyah, terj. Agil Husain alMunawwar, Keluasan dan Keluwesan Hukum Islam. Cet. I; Semarang: Toha Putra, 1993.

Suma, Muhammad Amin, dkk. Pidana Islam di Indonesia. Jakarta: Pustaka Firdaus, 2001.

Waluyo, Bambang. Pidana dan Pemidanaan. Cet. III; Jakarta: Sinar Grafika, 2008.

Zein, Satria Efendi M. Prinsip-Prinsip Dasar Hukum Jinayat dan Permasalahan Penerapannya Masa Kini, Mimbar Hukum, no. 20 tahun VI. Jakarta: al-Hikmah, 1995. 